\title{
The State of the Art of Paleoparasitological Research in the Old World
}

\author{
Françoise Bouchet ${ }^{+}$, Stéphanie Harter, Matthieu Le Bailly \\ Laboratoire de Paléoparasitologie, EA 3308, associé CNRS ESA 8045, U.F.R de Pharmacie, Université de Reims, 51, \\ rue Cognacq-Jay, 51096 Reims Cedex, France
}

Paleoparasitology in the Old World has mainly concerned the study of latrine sediments and coprolites collected from mummified bodies or archaeological strata, mostly preserved by natural conditions. Human parasites recovered include cestodes, trematodes, and nematodes. The well preserved conditions of helminth eggs allowed paleoepidemiological approaches taking into account the number of eggs found by archaeological stratum. Tentatively, sanitation conditions were assessed for each archaeological period.

Keywords: paleoparasitology - coprolites - mummies - platyhelminthes - nemathelminthes - Old World

Few parasitologists have had the opportunity to study the life of vanished populations by the study of the parasites they hosted. The evidence of parasitism has led to some remarkable inferences, including retracing prehistoric migration routes and thus contributing to the knowledge of the peopling of continents. "The Egyptomania" that once fascinated Europe resulted in the pioneering studies of Sir Marc Armand Ruffer (Ruffer 1910), but after that only only a few sporadic contributions appeared. For then on, up to the middle of the 20th century, parasites in archaeological material were recorded by a few parasitologists collaborating with archaeologists. But, somehow, paleoparasitology in Europe began to develop at the end of the past century. One wonders if the classic division between Human Sciences and Medical Sciences in European universities discouraged cooperation among scientists of both sides of these sectors.

We review here the contribution of the Old World Paleoparasitology to the knowledge of ancient human hostparasite relationships in attempting to understand the life of European populations throughout time. This review will treat at first the Platyhelminthes, Nemathelminthes, and then comment on protozoa findings in archaeological material.

\section{PLATYHELMINTHES}

Trematodes

\section{Dicrocoeliidae and Fasciolidae}

Both the Dicrocoeliidae and Fasciolidae have been found from the Pleistocene period up to historical times. Jouy-Avantin et al. (1999) identified Dicrocoelium eggs in a coprolite dated of 550,000 years ago in the Tautavel site (Caune de l'Arago). Two possible hosts were identified, both extinct today: the hyena (Crocuta spelaea) and

${ }^{+}$Corresponding author. Fax: +33-0-3-26-91.35 47. E-mail: francoise.bouchet@univ-reims.fr

Received 26 August 2002

Accepted 25 November 2002 the bear (Ursus speleaeus and $U$. ringeri). Such ancient contexts are extremely challenging. The eggs are extremely rare and their discovery requires a real tenacity on behalf of scientific observers. In addition, parasite life cycles may not correspond to those we know of today. Some intermediate or definitive hosts may have been replaced by other species or became extinct. It is necessary to take into account many variables regarding the complexity of parasite life cycles. Our Cartesian reasoning would always tilt for a simple cycle, monoxenous, but we have to have in mind that this type of reasoning is not always that of the parasites: "Why make it simple when one can make it complicated?" (Combes 1995).

During the Neolithic, Fasciola hepatica and Dicrocoelium sp. (Fig. 1) were present in the wetland prehistorical sites in Switzerland and France, such as in the archaeological sites of Arbon, dated of 3384-3370 BC, and in the archaeological site of Chalain, dated of 3200-2900 BC (Bouchet et al. 1996, Dommelier 2001, Le Bailly 2002). These trematode eggs were found in sediments, coprolites, and in the Hallstatt's mines, in which coprolites were sealed by salt (Aspöck et al. 1973, 1974, Aspöck \& Auer 1998).

There are few records for Bronze Age. Fasciola and Dicrocoelium were found again in Hallstat's salt mines and in the sub-aquatic Gresine site (Bourget Lake, France), for which excavations have just begun (Le Bailly 2001).

During the Gallo-Roman period and the Middle Ages these trematode infections accompany humans and their domestic animals. The material collected from rescue excavations in archaeological sites in the French cities of Paris, Montbeliard, Reims, and Bordeaux, as well as in Poland (Table I), showed the presence of these two trematodes. Ancient Europeans were hosts for F. hepatica and its presence showed that people ate salads made from dandelion (Taraxacum dens leonis), lambs lettuce (Valerianella olitoria), chicory (Cichorum intybus), bears' garlic (Allium ursinum), and watercress (Nasturtium officinale) or European marshwort (Apium nodiflorum). Guillaume de Villeneuve, in his Middle-Ages book dated of 1545 "The hundred and seven shouts of Paris" mention the shout of watercress sellers in the streets: "Vey ci bon cresson orlénois!". 


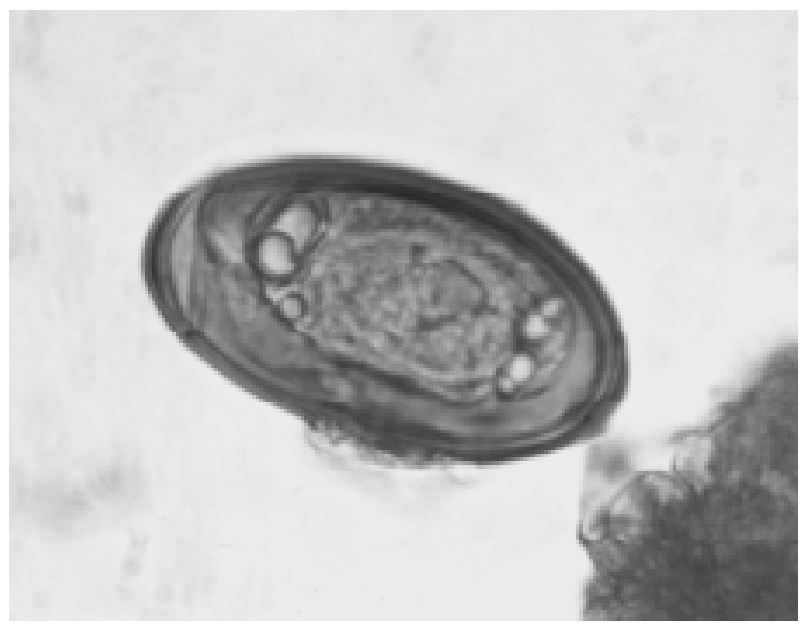

Fig. 1: Dicrocoelium sp. egg, 40 × $25 \mu \mathrm{m}$ (X1000), Chalain, Jura, France (Bouchet et al. 1996).

Regarding Dicrocoelium infection, it is rare among humans. However it is found in many other mammal hosts, including domestic animals. Its presence in ancient human feces may reflect pseudoparasitosis or, less likely, true human infection.

\section{Schistosomatidae}

Schistosoma haematobium eggs were the first parasite eggs recorded in archaeological material. They were found in Egyptian mummified bodies, well-characterized by their terminal spines (Ruffer 1910). The records for this parasite cover a period of time from $3000 \mathrm{BC}$ to $550 \mathrm{AD}$ (Ruffer 1910, Reyman 1976, Deelder et al. 1990, Miller et al. 1992, Contis \& David 1996). East Africa seems to be the center of dispersion of schistosomiasis and from there the infection dispersed to other parts of the world (Chamot \& Amat-Roze 1993). Emergence and dispersal of schistosomiasis along the Nile was confirmed by current research (Harter et al. 2002, current research) in High Nubia, by the finding of $S$. haematobium eggs in natural mummified bodies dated of $2400 \mathrm{BC}$ (Fig. 2). As proposed by Nozais (1987) this occurred gradually by nomad caravans and the slave trade along the Nile through the prehistoric Sahara.

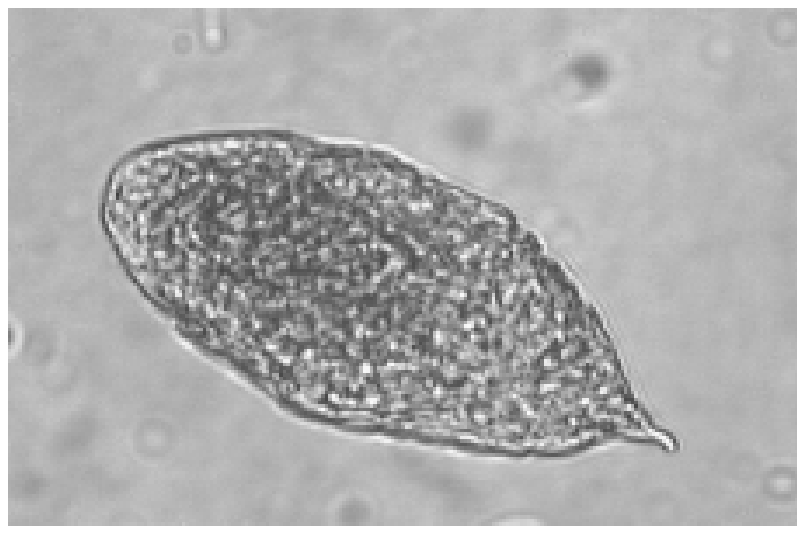

Fig. 2: Schistosoma haematobium egg, 124 x $50 \mu \mathrm{m}$ (X400), Saï Island, Nubia, Africa.
S. haematobium eggs were found in a pit adjacent to a 15th-16th century house, in France (Bouchet \& Paicheler 1995). In the same latrine S. mansoni eggs (Fig. 3) were also found (Bouchet et al. 2002). It is interesting to consider the presence of both parasites in the same context. Both urogenital and intestinal schistosomiasis are considered of African origin. Regarding the find of both species of schistosomes in France, it is possible that Europeans became infected during a trip to Africa. On the other hand, an infected African brought to France might have eliminated these eggs (Bouchet et al. 2002). It was a common practice during the 15th and 16th centuries to bring Africans to Europe. It is also interesting to note that in addition to the well preserved eggs, a fragmented worm body was found (Fig 4), showing the extremely good preservation conditions in this kind of environment (Bouchet \& Paicheler 1995).

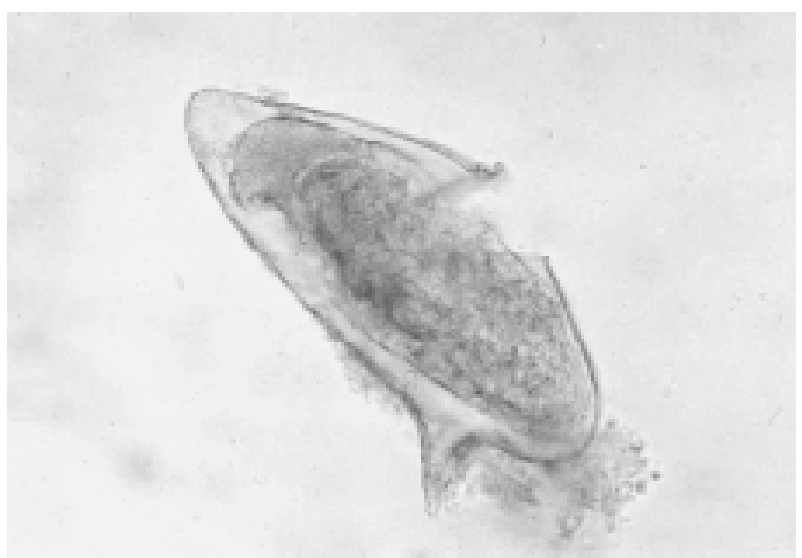

Fig. 3: Schistosoma mansoni egg, 142 x $58 \mu \mathrm{m}$ (X400), Montbéliard, France (Bouchet et al. 2002).

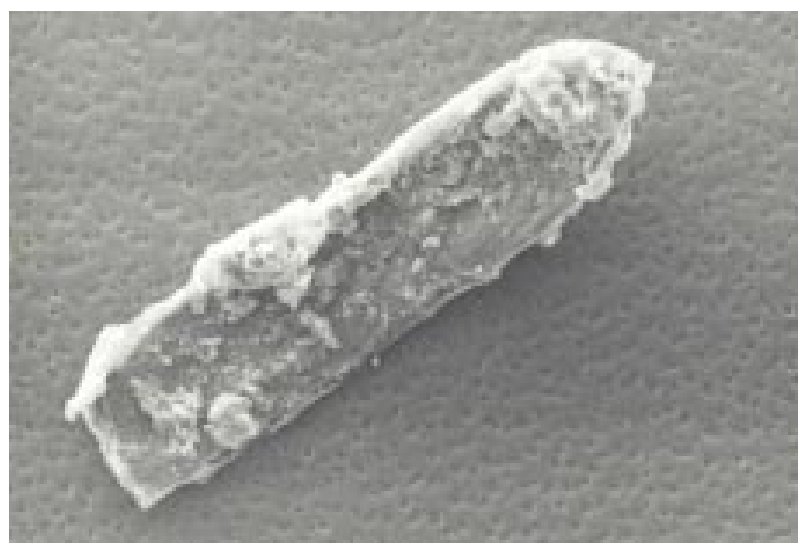

Fig. 4: Schistosoma sp. adult worm fragment showing two suckers (SEM X500), Montbéliard, France (Bouchet \&Paicheler 1995).

\section{Cestodes}

\section{Cyclophyllidea}

\section{Taenia}

The oldest date recorded for the association of Taenia spp. eggs with human remains is from the Neolithic period. Eggs were found in coprolites collected from the archaeological site of Chalain, France, dated of 3200-2900 
BC (Dommelier et al. 1998). Taenia spp. eggs were also found in Hallstat salt mines, dated to the end of the Neolithic period (Aspöck 1973).

Histological preparation of the small intestine of an Egyptian mummy, dated of 1198 to 1150 BC, revealed well preserved Taenia spp. eggs examined through scanning electron microscopy (Horne \& Lewin 1977). Recently, these parasite eggs were found in Nubian natural mummified bodies dated of 2400 years BC (Harter et al. current research).

Interesting observations have been made for the historic period, especially in France where research was done to interpret taeniid findings. In archaeological remains found in the wealthy homes occupied by the nobility (Louvre, Marly le Roi and Montbéliard), Taenia eggs were commonly found (Bouchet 1995, Bouchet \& Paicheler 1995, Bouchet et al 1998). During this time under-cooked meat, nearly raw, was eaten by nobles. On the other hand, in archaeological sites in the country, Taenia eggs were not found. The food consumed by the poor was mainly a soup prepared with small fragments of well-cooked meat.

\section{Pseudophyllidea}

Diphyllobothrium spp. eggs were found since Neolithic time, in Chalain and the wetland sites of Arbon and Concise (Fig. 5) (Dommelier 2001, Le Bailly 2002). This is a freshwater fish parasite, from which the larvae are transmitted to carnivores where they develop into adults in the intestine. Eggs eliminated with feces are ingested by crustaceans or fish. Humans acquire infection from raw fish consumption.

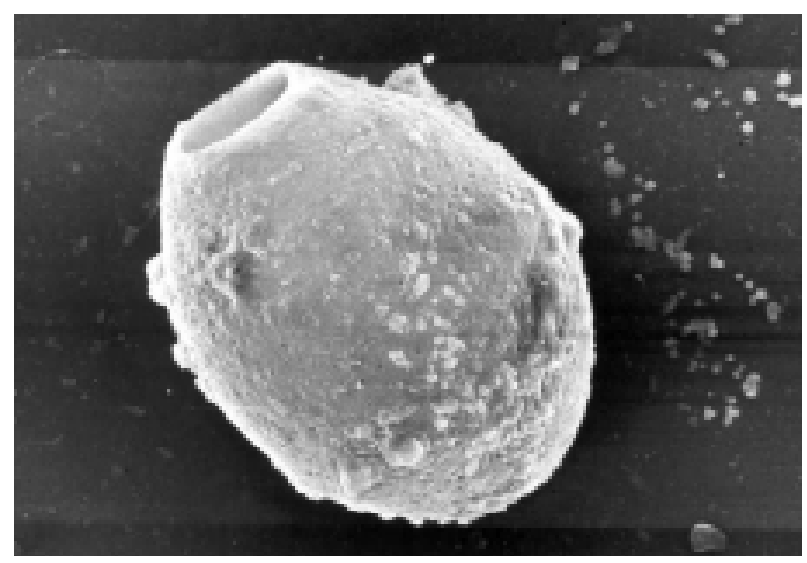

Fig. 5: Diphyllobothrium sp. egg, 51 x $39 \mu \mathrm{m}$ (SEM X1500), Chalain, Jura, France.

During the Gallo-Roman period and the Middle Ages, Diphyllobthrium spp. eggs were found in archaeological sites in Germany (Jansen et al. 1962, Herrmann 1987) and in France (Bouchet et al. 2001). Again, only in the latrines of rich houses were parasite eggs found (Table). As shown by archaeological finds, salted or raw fish and beef were consumed at the time by the wealthy. Meat preparation procedures did not kill parasite larvae.

\section{Nemathelminthes \\ Ascaridae}

Ascaris eggs are extremely abundant in the European mediaeval sites and are indicative of fecal pollution (Taylor 1955, Pike 1967, Greig 1981, 1982, Bouchet 1994, 1995, Bouchet \& Paicheler 1995). The number and abundance of the eggs can indicate degrees of fecal pollution and are used also to differentiate among latrines, cesspits, wells, iceboxes, and agriculture devices such as silos (Bouchet 1994).

Ascaris lumbricoides was considered a ubiquitous parasite in paleoparasitological studies in historical sites. However, paleoparasitological analysis of prehistoric sites in Europe does not confirm this hypothesis for older periods. Ascaris was absent in organic remains dated to the Neolithic period, in Switzerland and in France, in the archaeological sites of Arbon, dated of 3384-3370 BC, and Chalain, dated of 3200-2900 BC (Bouchet et al. 1996, Dommelier 2001). Presently there is no explanation for its absence. Also, the Ötzi mummy was not infected by ascarid roundworms (Aspöck et al. 1996).

The oldest recorded dates for Ascaris are 800 to 350 $\mathrm{BC}$, the Iron Age period, in human coprolites of Hallstatt salt mines (Aspöck et al. 1973), and from Prussian mummies dated of 600 BC (Szidat 1944). Ascaris eggs were found in a Egyptian mummy, dated of the Ptolomaïc period 170 years BC (Cockburn et al. 1975).

Ascaris sp. eggs (Fig 6) were found in coprolites from the Pleistocene Arcy-sur-Cure cave in France which was inhabited by humans and bears (Bouchet et al. 1996). The zoological origin of the coprolites, whether bear or human, was not confirmed. Parasitologists believed that $A$. lumbricoides became a human parasite after pig domestication. If it was parasitizing humans of Pleistocene populations before pig domestication, then the theory of an origin from the pig species, A. suum, is untrue. Because of this, the Arcy-sur-Cure data upset the conventional wisdom. However, other findings are needed to confirm the ancient relationship of $A$. lumbricoides to humans. This problem might be resolved by the application of molecular biology through which the ascarid genomic origin may be traced (Loreille et al. 2001).

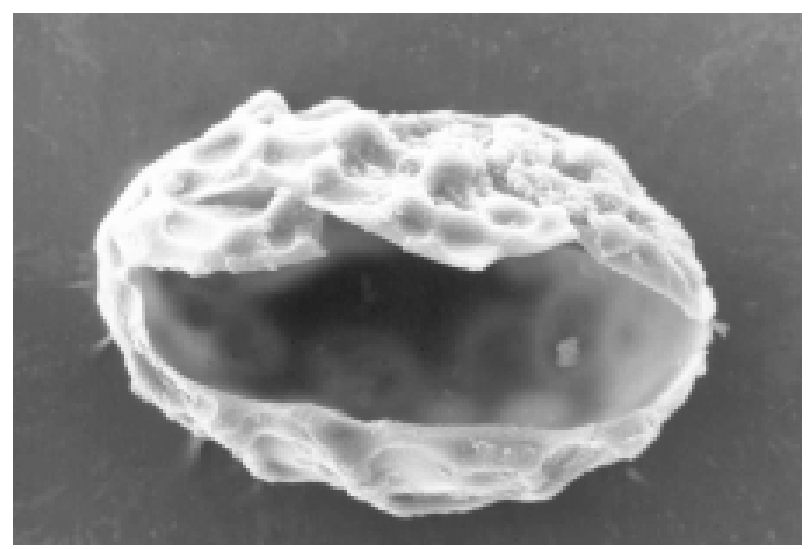

Fig. 6: Ascaris sp. broken egg, 57 x $51.3 \mu \mathrm{m}$ (SEM X1500), Arcysur-Cure, France (Bouchet et al. 1996). 
TABLE

Parasites find for the Middle-Age period in Europe

\begin{tabular}{|c|c|c|c|c|c|c|c|}
\hline Authors & Date & Samples & Site & Datations & Nematode & Trematode & Cestode \\
\hline Taylor & 1955 & $\begin{array}{l}\text { Sediments } \\
\text { Latrines }\end{array}$ & $\begin{array}{l}\text { England } \\
\text { Winchester }\end{array}$ & XI-XII & $\begin{array}{l}\text { Trichuris } \\
\text { Ascaris }\end{array}$ & Dicrocoelium & \\
\hline Grzywinski & $\begin{array}{l}1959 \\
1960\end{array}$ & Coprolites & Slaves & XI-XIII & & Fasciola & \\
\hline Pike & 1967 & Coprolites & & XI-XIII & $\begin{array}{l}\text { Trichuris } \\
\text { Ascaris }\end{array}$ & $\begin{array}{l}\text { Fasciola } \\
\text { Dicrocoelium }\end{array}$ & \\
\hline Greig & 1981 & $\begin{array}{l}\text { Sediments } \\
\text { Latrines }\end{array}$ & $\begin{array}{l}\text { Great Britain } \\
\text { Worcester }\end{array}$ & $X V$ & $\begin{array}{l}\text { Trichuris } \\
\text { Ascaris }\end{array}$ & & \\
\hline Moore & 1981 & $\begin{array}{l}\text { Sediments } \\
\text { Latrines }\end{array}$ & England & $X-X V$ & $\begin{array}{l}\text { Trichuris } \\
\text { Ascaris }\end{array}$ & & \\
\hline Greig & 1982 & $\begin{array}{l}\text { Sediments } \\
\text { Latrines }\end{array}$ & $\begin{array}{l}\text { England } \\
\text { Londres }\end{array}$ & XV-XVI & $\begin{array}{l}\text { Trichuris } \\
\text { Ascaris }\end{array}$ & & \\
\hline Legendre et al. & 1986 & Latrines & $\begin{array}{l}\text { France } \\
\text { Strasbourg }\end{array}$ & XV-XVI & $\begin{array}{l}\text { Trichuris } \\
\text { Ascaris }\end{array}$ & & \\
\hline Rouffignac & 1987 & $\begin{array}{l}\text { Coprolites } \\
\text { Sediments }\end{array}$ & Europe & XIII-XV & $\begin{array}{l}\text { Ascaris } \\
\text { Trichuris }\end{array}$ & $\begin{array}{l}\text { Fasciola } \\
\text { Dicrocoelium }\end{array}$ & Diphyllobothrium \\
\hline Herrmann & 1988 & $\begin{array}{l}\text { Sediments } \\
\text { Latrines }\end{array}$ & Germany & & $\begin{array}{l}\text { Ascaris } \\
\text { Enterobius }\end{array}$ & & $\begin{array}{l}\text { Diphyllobothrium } \\
\text { Tania }\end{array}$ \\
\hline Bouchet et al. & 1989 & $\begin{array}{l}\text { Coprolites } \\
\text { Sediments } \\
\text { Latrines }\end{array}$ & $\begin{array}{l}\text { France } \\
\text { Paris }\end{array}$ & XII-XV & $\begin{array}{l}\text { Trichuris } \\
\text { Ascaris } \\
\text { Toxocara } \\
\text { Acanthocephala } \\
\text { Ancylostoma }\end{array}$ & & Tania \\
\hline Bouchet et al. & 1991 & Sediments & $\begin{array}{l}\text { France } \\
\text { Paris }\end{array}$ & XVII-XVIII & $\begin{array}{l}\text { Trichuris } \\
\text { Ascaris } \\
\text { Toxocara } \\
\text { Heterakis } \\
\text { Toxascaris } \\
\text { Filicolis } \\
\text { Syngamus } \\
\text { Ancylostoma }\end{array}$ & & \\
\hline Bouchet & 1991 & $\begin{array}{l}\text { Sediments } \\
\text { Pits } \\
\text { Garbage dumps }\end{array}$ & $\begin{array}{l}\text { France } \\
\text { Beauvais }\end{array}$ & XIII-XVII & $\begin{array}{l}\text { Trichuris } \\
\text { Ascaris } \\
\text { Heterakis } \\
\text { Capillaria }\end{array}$ & & \\
\hline Bouchet & 1993 & Sediment & $\begin{array}{l}\text { France } \\
\text { Paris }\end{array}$ & XIV-XV & Trichuris & $\begin{array}{l}\text { Fasciola } \\
\text { Dicrocoelium }\end{array}$ & \\
\hline Bouchet & 1994 & $\begin{array}{l}\text { Sediments } \\
\text { Animals } \\
\text { Charavines }\end{array}$ & $\begin{array}{l}\text { France } \\
\text { Paris }\end{array}$ & XVIII & $\begin{array}{l}\text { Toxocara canis } \\
\text { Parascaris }\end{array}$ & $\begin{array}{l}\text { Fasciola } \\
\text { Dicrocoelium }\end{array}$ & \\
\hline $\begin{array}{l}\text { Bouchet \& } \\
\text { Paicheler }\end{array}$ & 1995 & $\begin{array}{l}\text { Sédiment } \\
\text { Latrines }\end{array}$ & $\begin{array}{l}\text { France } \\
\text { Montbéliard }\end{array}$ & $X V$ & & Schistosoma sp. & Taenia \\
\hline Bouchet et al & 1995 & Latrine & $\begin{array}{l}\text { Belgium } \\
\text { Raversijde }\end{array}$ & $X V$ & $\begin{array}{l}\text { Trichuris } \\
\text { Ascaris }\end{array}$ & & Tania \\
\hline Bouchet & 1995 & $\begin{array}{l}\text { Sediment } \\
\text { Coprolites }\end{array}$ & $\begin{array}{l}\text { France } \\
\text { Paris }\end{array}$ & & $\begin{array}{l}\text { Trichuris } \\
\text { Ascaris }\end{array}$ & $\begin{array}{l}\text { Fasciola } \\
\text { Dicrocoelium }\end{array}$ & \\
\hline Bouchet et al. & 1997 & $\begin{array}{l}\text { Sediments } \\
\text { Channeling }\end{array}$ & $\begin{array}{l}\text { France } \\
\text { Vincennes }\end{array}$ & 800 ap. J.C. & $\begin{array}{l}\text { Trichuris } \\
\text { Ascaris }\end{array}$ & Fasciola & \\
\hline Bouchet et al. & 1998 & Coprolites & $\begin{array}{l}\text { France } \\
\text { Marly le Roy }\end{array}$ & XVII-XVIII & $\begin{array}{l}\text { Trichuris } \\
\text { Ascaris }\end{array}$ & Fasciola & Tania \\
\hline Bouchet et al. & 2002 & $\begin{array}{l}\text { Sediments } \\
\text { Latrines }\end{array}$ & $\begin{array}{l}\text { France } \\
\text { Montbéliard }\end{array}$ & $X V$ & & $\begin{array}{l}\text { Schistosoma } \\
\text { mansoni }\end{array}$ & \\
\hline
\end{tabular}




\section{Trichuridae}

Today, A. lumbricoides and Trichuris trichiura are the most common human intestinal parasites in most parts over the world where sanitation conditions are poor. This was also true in European archaeological sites dated of historical times, but not for more ancient periods as discussed above for Ascaris. The association of Ascaris and Trichuris with fecal contamination seems inseparable. Both parasites need a development phase on the soil, in adequate humid conditions.

Well preserved Trichuris eggs (Fig. 7) were found in the Neolithic wetland villages in western Europe, sometimes with the embryo inside and others filled with crystals of iron pyrites, which demonstrates antiquity (Bouchet et al. 1995). It was the only parasite found in the Hauslabjoch's mummy, Ötzi, dated of 3200 BC (Aspöck et al. 1995, 1996).

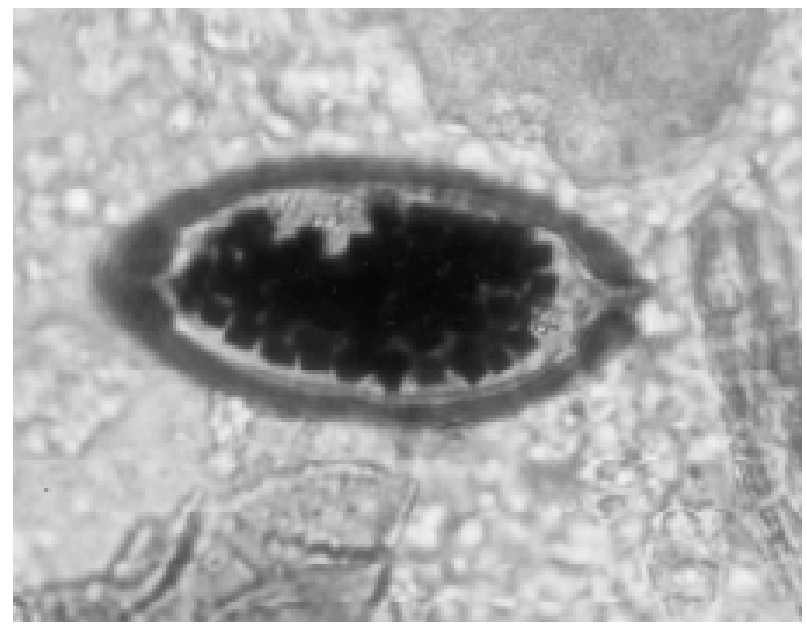

Fig. 7: Trichuris sp. egg with iron pyrite crystals inside, $53 \times 28 \mu \mathrm{m}$ (X1000), Chalain, Jura, France (Bouchet et al. 1995).

During our current research of natural mummified bodies from the old territory of Nubia, NE Africa, we found Trichuris eggs in visceral contents kept in Canopic jars during mummification process. Mummies were dated of 2400 years $\mathrm{BC}$ to 1500 years $\mathrm{AD}$, corresponding to the high Nile valley, in high Nubia, in the island of Saï and of the Kerma site. As Egyptians and Nubians maintained an intensive trade during this time it is possible to think that this was an infection common to Egyptians too (Harter et al. current research).

\section{Capillaridae}

Capillaria eggs were found abundantly in three Neolithic wetland sites of the Alps and in the Jura region, in France (Chalain, Arbon, and Concise). Of 23 human coprolites from Chalain, 21 were positive for Capillaria eggs (Bouchet 1997, Bouchet et al. 1997). Eggshells exhibited different ornamentation (Figs 8,9), and three species can be identified parasitizing humans, C. aerophila, C. hepatica, and C. philippensis. The first two species have rats and mice as intermediate hosts. To our present knowledge, both rodents were introduced in Europe after the Neolithic. Therefore, more research has to be done to explain the presence of these parasites at this earlier time.

It is not easy to place humans in the biological cycle of the parasite. Did they have played the role of definitive hosts, intermediate hosts, false, or paratenic hosts? In the case of obligatory heteroxeny the same animal can be a definitive host if larva were ingested, or intermediate host in the case of egg ingestion. As suggested by Combes (1995), parasites may have changed life cycles according

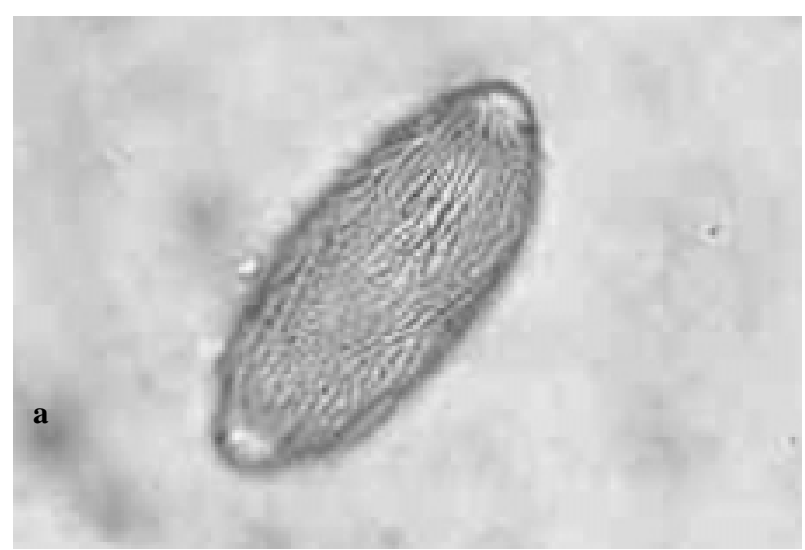

b

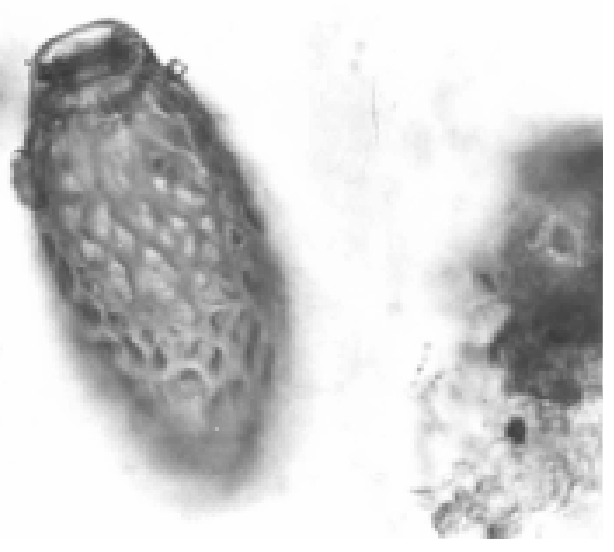

Fig. 8a,b: Capillaria sp. egg showing striated egg shell, $61 \times 27 \mu \mathrm{m}$ (X400), Arbon, Thurgovie, Swiss (Bouchet 1997).

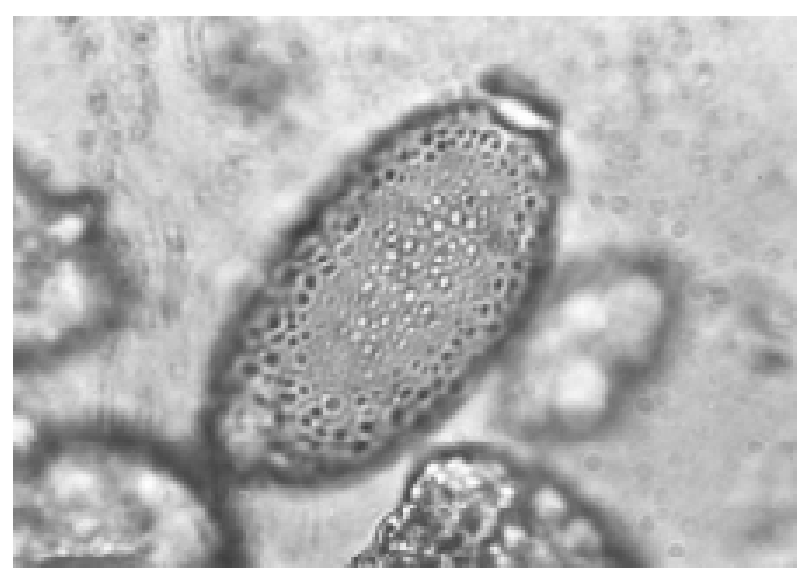

Fig. 9: Capillaria sp. egg showing granular eggshell, 56 × $38 \mu \mathrm{m}$ (X600), Chalain, Jura, France (Bouchet 1997). 
to available hosts, especially when such a long period of time is taken into account. Paleoenvironment context may have provided other alternatives for parasites to complete their biological cycles.

\section{Protozoa}

Paleoparasitological evidence of protozoal infection is scarce. Although protected by a cystic membrane, protozoa are easily destroyed by the diagenic process. Up to now malaria infection was diagnosed in Egyptian mummies by using immunological techniques (Miller et al. 1994, Cerutti et al. 1999). Giardia duodenalis antigen was detected in human coprolites from European and American archaeological sites, showing the utility of these immunoassays to detect protozoal infections (Gonçalves et al. 2002). Because protozoa cysts preserve poorly, this technique can improve the diagnosis of protozoal infections, in addition to molecular approaches.

\section{CONCLUSION}

Paleoparasitologists are constructing a parasite fossil record once regarded as nonexistent. However, the older the material the greater the loss of parasites, due to taphonomic processes. Furthermore, one must consider the possibility of parasite extinction as well as its host extinction. In that case the diagnosis is much more difficult.

Crowding seems to facilitate parasite preservation. The epidemiological transition from hunter-gathering subsistence to sedentary agriculture changed many aspects of parasite diseases in human prehistoric groups. During Neolithic settlements the crowding effect and the presence of domesticated animals contributed to change the human parasitic fauna. Anthropozoonoses appeared and were established as common to humans and their domestic animals.

It is also important to note the exceptional favorable conditions offered by wet environments. The European archaeological sites located near or presently submerged by water revealed the best preserved parasite eggs. So, it is not surprisingly that these wetlands are the sites mostly studied by malacologists, archaeozoologists, palynologists, etc., who search for well preserved organic remains. Paleoparasitologists also focus on wet deposits. Parasitologists, thus, should be able to infer, with a help from other disciplines, parasite transmission life cycles.

The European historical period seems to be written on an Ascaris and Trichuris parchment. The well known chronostratigraphy of the European archaeological sites (Table I) has allowed interpretations of sanitation conditions and hygenic habits of some well-defined groups. Food habits of rich and poor in the country and urban centers were shown to be contrasting, which influenced intestinal parasite finds.

Finally, we would like to call attention to other parasites, which are not commonly found in humans but that may have infected them in the past. Associated with human archaeological sites are Metastrongylus sp., Toxocara sp., Passalurus sp., Paramphistomum sp., Alaria sp., and Parascaris sp. eggs (Beeching et al. 1993, Bouchet \& Bentrad 1997, Bouchet et al. 2000). As done in other parts of the world (Ferreira et al. 1991), it is necessary to develop studies regarding parasite infections in other animals to understand past environments.

Paleoparasitology in contributing to the history of parasite-host relationships as well as opening a new page to study the spatiotemporal dimension of parasitism. Through paleoparasitological studies, the emergence and reemergence of infectious diseases can be better understood through time.

\section{REFERENCES}

Aspöck H, Auer H 1998. Tabellen und Illustationen zur Laboratoriumsdiagnostik von Parasitosen. Teil 2: Biologische Grundlagen und Übersicht der Untersuchungsmethoden. Labor Aktuell (Roche Austria)5: 9-16.

Aspöck H, Auer H, Picher O 1995. The mummy from the Hauslabjoch: a medical parasitology perspective. Alpe Adria Microbiol J 2: 105-114.

Aspöck H, Auer H, Picher O 1996. Trichuris trichiura eggs in the neolithic glacier-mummy from the Alps. Parasitol Today 12: 255-256.

Aspöck H, Barth FE, Flamm H, Picher O 1974. Parasitäre Erkrankungen des Verdauungstraktes bei prähistorischen Bergleuten von Hallstatt und Hallein (Österreich). Mit Anthropol Ge Wien 103 (1973): 41-47.

Aspöck H, Flamm H, Picher O 1973. Darmparasiten in menschlichen Exkrementen aus prähistorischen Salzbergwerken der Hallstatt-Kultur (800-350 v. Chr.). Zlb Bakt Hyg I Ab Orig 223: 549-558.

Beeching A, Moulin B 1983. Sédiments anthropiques et coprolithes animaux: modestes contributions à de grands problèmes? Bull Soc Préhist Fr 80: 72-74.

Bouchet F 1991. Étude parasitologique des chantiers archéologiques de Beauvais (Oise). Rev Archéol Picardie 3/4: 293-294.

Bouchet F 1993. Apport de la Parasitologie sur les chantiers archéologiques. L'exemple de la ville de Paris. Mém Groupement Archéol de Seine-et-Marne 1: 55-61.

Bouchet F 1994. Analyse parasitologique des Logis de la Cour des Suisses. Archéologia: Les Dossiers d'Archéologie 190: 87 and 92-93.

Bouchet F 1995. Recovery eggs from archaeological excavations of the Grand Louvre (Paris, France). J Parasitol 80: 785-786.

Bouchet F 1997. Intestinal capillariasis in neolithic inhabitants of Chalain (Jura, France). The Lancet 349: 256.

Bouchet F 1998. Perspectives d'une discipline biologique en Archéologie: la Paléoparasitologie. Actes du Colloque International d'Anthropologie de Gènes, 8-9 Juin 1996. Ethnomedicina 1: 33-38.

Bouchet F, Bentrad S 1997. Recovery of equine helminth eggs in a mediaeval lacustrine settlement (Charavines, Isère, France). Vet Rec 141: 601-602.

Bouchet F, Paicheler JC 1995. Presumption of Bilharziose on an archaeological site from $\mathrm{XV}^{\circ}$ century in Montbéliard (Doubs, France) CR Acad Sci Sér III 318: 811-814.

Bouchet F, Audoin F, Léger N, Marchais R, Baucheron F, Munoz Lacasta J 1989. Etude parasitologique des coprolithes et des sédiments de trois ensembles clos de la rue de Lutèce (Ile de la Cité) à Paris. Archeom 13: 13-21.

Bouchet F, Baffier D, Girard M, Morel Ph, Paicheler JC, David F 1996. Palaeoparasitology in a Pleistocene context : initial observations in the Grande Grotte at Arcy-sur-Cure (Department of the Yonne, France). CR Acad Sci Sér III 319: 147-151.

Bouchet F, Bentrad S, Dommelier S, Paicheler JC, Pétrequin P 1997. Capillarioses intestinales: nématodose du Néolithique? Bull Soc Fr Parasitol 15: 49-54. 
Bouchet F, Bentrad S, Martin C 2001. Analyse paleoparasitologique. In Le quartier Gallo-Romain de la rue de Venise et sa réoccupation à l'époque Moderne. Archéologie Urbaine. Bull Soc Arch Champenoise 2-3: 148-150.

Bouchet F, Bentrad S, Paicheler JC 1998. Enquête épidémiologique sur les helminthiases à la cour de Louis XIV. Médecine/Sciences 14: 463-466.

Bouchet F, Ervynck A, Raveschot P 1991. Rijk, maar proper? Parasitologisch onderzoek van een put uit de Schepenhyuisstraat. Stadsarcheologie 15: 8-13.

Bouchet F, Harter S, Paicheler JC, Aráujo A, Ferreira LF 2002. The first recovery of Schistosoma mansoni eggs from a latrine in Europe (15th-16th). J Parasitol 88: 404-405.

Bouchet F, Lavazec C, Nattier V, Dommelier S, Bentrad S, Paicheler JC 2000. Etude de la parasitofaune du site médiéval de Charavines (Lac de Paladru, Isère, France). Bull Soc Zool Fr 125: 205-215.

Bouchet F, Pétrequin P, Paicheler JC, Dommelier S 1995. Première approche paléoparasitologique du site néolithi-que de Chalain (Jura, France). Bull Soc Path Ex 88: 265-268.

Cerutti N, Marin A, Rabino Massa E, Savoia D 1999. Immunological investigation of Malaria and new perspectives in Paleopathological studies. J Biol Res 75: 17-20.

Chamot G, Amat-Roze JM 1993. Les Bilharzioses. Revue du Praticien 43: 401-404.

Cockburn A, Barraco RA, Reyman TA, Peck WH 1975. Autopsy of an Egyptian mummy. Science 187: 1155-1160.

Combes Cl 1995. Interactions Durables. Ecologie et Évolution du Parasitisme, Collection Ecologie, Masson, Paris 26, 524 pp.

Contis G, David AR 1996. The epidemiology of bilharzia in ancient Egypt: 5000 years of schistosomiasis. Parasitol Today 12: 253-255.

Deelder AM, Miller RL, Jonge N de, Krijger FW 1990. Detection of schistosome antigen in mummies. The Lancet 335: 724.

Dommelier-Espejo S 2001. Contribution à l'Étude Paléoparasitologique des Sites Néolithiques en Environnement Lacustre dans les Domaines Jurassien et Péri-Alpin, PhD Thesis, U.F.R de Sciences Exactes et Naturelles, Université de Reims Champagne-Ardenne, 248 pp., non éditée.

Dommelier S, Bentrad S, Bouchet F, Paicheler JC, Pétrequin P 1998. Parasitoses liées à l'alimentation chez les populations du site néolithique de Chalain (Jura, France). Anthropozoologica 27: 41-49.

Ferreira LF, Aráujo A, Confalioneri UEC, Chame M, Gomes DC 1991. Trichuris eggs in animal coprolites dated from 30.000 years ago. J Parasitol 77: 491-493.

Gonçalves MLC, Araujo A, Duarte R, Reinhard K, Bouchet F, Ferreira LF 2002. Detection of Giardia duodenalis antigen in coprolites using a commercially available enzyme immunoassay. Trans $R$ Soc Trop Med Hyg in press.

Greig J 1981. The investigation of a medieval Barrel-latrine from Worcester. J Archaeol Sci 8: 265-282.

Greig J 1982. Garderobes, sewers, cesspits and latrines. Curr Archaeol 85: 49-52.

Grzywinski L 1959-1960. Analysis of feces from the middle age period. Zool Poloniae 10: 195-199.

Harter S, Maureille B, Kramar Ch, Berger-el Naggar C, Geus F, Bouchet F. Etudes paléoparasitologiques des momies naturelles des sites archéologiques de Haute Nubie: Ile de Saï, Kerma et Sedeinga. Bull et Mem Soc Anthrop de Paris, Soumis.
Herrmann B 1987. Parasitologische Untersuchung mittelalterlicher Kloaken. Mensch und Umwelt im Mittelalter 3: 160-169.

Herrmann B 1988. Parasite Remains from Mediaeval Latrine Deposits: an Epidemiologic and Ecologic Approach. Note et monographie technique $\mathrm{n}^{\circ} 24,135-142$, CNRS, Paris.

Horne PD, Lewin PK 1977. Electron microscopy of mummified tissue: autopsy of an Egyptian mummy. Can Med Ass $J$ 117: 472-473.

Jansen J Jr, Over HJ 1962. The occurrence of parasites in protohistorical material from north-west Germany. Tijdschr Diergeneesk 87: 1377-1379.

Jouy-Avantin F, Combes C, Lumley H (de), Mikovsky JC, Mone H 1999. Helminth eggs in animal coprolites from Middle Pleistocene site in Europe. J Parasitol 85: 376-379.

Le Bailly M 2001. Etude de l'helminthofaune du site de Grésine (Lac du Bourget, France). Mémoire de Maîtrise Biologie Cellulaire et Physiologie, Biologie Générale et Sciences de la Terre et de l'Univers, U.F.R Sciences Exactes et Naturelles, Université de Reims Champagne-Ardenne, 39 pp., non publié.

Le Bailly M 2002. Etude paléoparasitologique du site néolithique d'Arbon-Bleiche 3 (Thurgovie, Suisse). Mémoire de Diplôme d'Etudes Approfondies, Muséum National d'Histoire Naturel, Paris V, 70 pp., non publié.

Legendre JP, Marie J, Rieb JP 1986. Contribution à l'Étude de l'État Sanitaire de la Population Strasbourgeoise à la Fin du Moyen-Age. Archéologie et Médecine, APDCA, Juanles-Pins, 1987.

Loreille O, Roumat E, Verneau O, Bouchet F, Hannï C 2001. Ancient DNA from Ascaris: Extraction amplification and sequence from eggs collected in coprolites. Int J Parasitol 31: 1101-1106.

Miller RL, Armelagos GJ, Ikram S, Jonge N de, Krijger FW, Deelder AM 1992. Palaeoepidemiology of schistosoma infection in mummies. Br Med J 304: 555-556.

Miller RL, Ikram S, Armelagos GJ, Walker R, Harer WB, Shiff CJ, Baggett D, Carrigan M, Maret SM 1994. Diagnosis of Plasmodium falciparum infections in mummies using the rapid manual ParaSight ${ }^{\mathrm{TM}_{-}}$F test. Tran $R$ Soc Trop Med Hyg 88: 31-32.

Moore PD 1981. Life seen from a medieval latrine. Nature 294: 614.

Nozais JP 1987. Hypothèses sur le rôle du Sahara préhistorique dans la répartition de certaines affections parasitaires et hématologiques. Bull Soc Path Ex 80: 121-131.

Pike AW 1967. The recovery of parasite eggs from ancient cesspit and latrine deposits: an approach to the study of early parasite infections. In DR Brothwell, AJ Sandison, Springfield (eds), Diseases in Antiquity, III, p. 184-188.

Reyman TA 1976. Schistosomal cirrhosis in an Egyptian mummy. Yearbook Phys Anthropol 20: 356-358.

Rouffignac C de 1987. Mediaeval man and his worms. Biologist 34: 187-190.

Ruffer MA 1910. Note on the presence of Bilharzia haematobia in Egyptian mummies of the Twentieth dynasty (12501000 BC). Br Med J I: 16.

Szidat L 1944. Uber die Erhaltungsfähigkeit von Helmintheneiern in Vor- und Frühgeschichtlichen Moorleichen. Z Parasitenk 13: 265.

Taylor EL 1955. Parasitic helminths in mediaeval remains. Vet Rec 67: 216-218. 